\title{
Right-lateral offset associated with the most recent earthquake on the Ikeda fault of the Median Tectonic Line, southwest Japan, revealed by ground-penetrating radar profiling
}

\author{
Adi Patria ${ }^{1,4}$, Haruo Kimura ${ }^{2}$, Yoshihiro Kitade ${ }^{3}$ and Hiroyuki Tsutsumi $3^{3^{*}}$
}

\begin{abstract}
The Median Tectonic Line (MTL) is an arc-parallel strike-slip fault that accommodates much of the arc-parallel component of the oblique convergence of the Philippine Sea and Eurasian plates at the Nankai Trough. The MTL in Shikoku is one of the fastest-slipping faults in Japan, with a late Quaternary right-lateral slip rate of 5-10 mm/yr. To estimate the right-lateral slip amounts of the past faulting events on the MTL, we acquired 2D and pseudo-3D ground-penetrating radar (GPR) sections across the ENE-trending Ikeda fault of the MTL in eastern Shikoku. We conducted the GPR surveys at the Higashi-Miyoshi site, where two terrace riser offsets mark the active fault trace. The $2 \mathrm{D}$ lines were about 28-64 m long, and the pseudo-3D data were sized $20 \mathrm{~m} \times 30 \mathrm{~m}$ with a $0.5-\mathrm{m}$ inline spacing. We used $50 \mathrm{MHz}$ GPR antennas and conducted wide-angle measurements to estimate the electromagnetic wave velocity. We identified three paleochannels on the final depth-converted GPR sections, and two of them are deflected by the fault. A paleochannel at 0.6-1.4 m depth is observed on all inline sections of the pseudo-3D GPR data. We built a 3D model of this paleochannel and estimated the right-lateral and vertical displacements of $\sim 3.5 \mathrm{~m}$ and $\sim 0.5 \mathrm{~m}$, respectively. This paleochannel offset is probably caused by the most recent surface-rupturing earthquake on the lkeda fault, which may be the 1596 Keicho-Fushimi earthquake. This study demonstrates the usefulness of the GPR surveys to identify geological features displaced laterally and vertically by the most recent surface-rupturing earthquake.
\end{abstract}

Keywords: Median Tectonic Line (MTL), Active fault, Ground-penetrating radar (GPR), 3D modeling, Earthquake geology

\footnotetext{
*Correspondence: htsutsum@mail.doshisha.ac.jp

${ }^{3}$ Department of Environmental Systems Science, Faculty of Science and Engineering, Doshisha University, 1-3 Tatara-Miyakodani, Kyotanabe, Kyoto 610-0394, Japan

Full list of author information is available at the end of the article
}

\section{Introduction}

The Japanese Islands are a seismically active region located at the convergence zone of the Eurasian, North American, Philippine Sea, and Pacific plates (Fig. 1a). The Pacific plate subducts beneath the North American plate at the Japan Trench at a rate of $\sim 10 \mathrm{~cm} / \mathrm{yr}$, while the Philippine Sea plate subducts obliquely beneath the Eurasian plate at the Nankai Trough at a rate of $\sim 4 \mathrm{~cm} / \mathrm{yr}$ (DeMets et al. 2010). This oblique convergence partitions into trench-parallel and trench-normal slip components. The trench-parallel slip is chiefly accommodated by the dextral Median Tectonic Line (MTL) (Fitch 1972) and a 
broad shear zone to the north (Sugiyama 1994). In this paper, we use the term "the MTL terrane boundary" for the geological boundary between two metamorphic belts in the inner and outer zone of southwest Japan, whereas the term "the MTL" for the active right-lateral strike-slip faults might have reactivated the MTL terrane boundary in the late Quaternary.

The MTL terrane boundary forms a major tectonic boundary in southwest Japan between the low pressurehigh temperature Ryoke metamorphic belt to the north and the high pressure-low temperature Sambagawa metamorphic belt to the south for $1000 \mathrm{~km}$ (Ito et al. 1996). Tectonic geomorphology indicates that the late Quaternary movement of the MTL is predominantly right-lateral strike-slip with vertical slip less than one-tenth of horizontal slip (Okada 1980). Tsutsumi and Okada (1996) summarized that the late Quaternary slip rate varies along the MTL; $1-3 \mathrm{~mm} / \mathrm{yr}$ in western Kinki, 5-10 mm/ $\mathrm{yr}$ in Shikoku, and less than $1 \mathrm{~mm} / \mathrm{yr}$ in Kyushu. Paleoseismological studies indicate that surface-rupturing earthquakes repeatedly occurred on the MTL, and all portions of the MTL in Shikoku may have ruptured in the sixteenth century AD (Goto et al. 2001; Morino and Okada 2002; Tsutsumi and Okada 1996). Tsutsumi and Goto (2006) revealed the horizontal slip amounts associated with the most recent earthquakes on the MTL in Shikoku based on displaced artificial and geomorphic features. Several 3D trench surveys were also conducted to identify piercing point offsets associated with the most recent surface-faulting event (Goto et al. 2003; Tsutsumi et al. 1991).

However, due to extensive human modification along the fault, offset geomorphic features are sparse and additional data are required to discuss the detailed slip distribution of the MTL. The ground-penetrating radar (GPR) is commonly used to image shallow subsurface structures (Benson 1995; Cai et al. 1996). In this study, we mapped the offset subsurface features associated with the past surface-rupturing earthquakes using the GPR method across the Ikeda fault of the MTL in Shikoku. This paper presents our interpretation of the GPR data and the 3D modeling of a selected paleochannel to identify the horizontal and vertical displacements associated with the most recent faulting events.

\section{Methodology}

\subsection{GPR data acquisition, processing, and interpretation}

GPR profiling is a commonly used geophysical method, which transmits the electromagnetic wave signal to the subsurface and records wave reflections, for imaging shallow subsurface structures (Davis and Annan 1989; Jol 2008). The penetration depth and the vertical resolution depend on the antennas' frequency under the assumption that the GPR instrument transmits the same power (Davis and Annan 1989; Jol 2008). The penetration depth is inversely proportional to the frequency. The $50 \mathrm{MHz}$ antennas can penetrate up to $10 \mathrm{~m}$ deep depending on the geological conditions (Smith and Jol 1995). The vertical resolution of the subsurface profiling using reflection wave follows the $1 / 4$ wavelength criterion (Sherrif and Geldart 1995). The signal weakens as it propagates through the deeper subsurface. The GPR measurement is suitable for shallow geological investigation of active faults and has been widely used to assess faulting activities (e.g., Chow et al. 2001; Malik et al. 2007; Slater and Niemi 2003). In the last two decades, the pseudo-3D GPR technique has also been applied to study active faults for better imaging of subsurface structures, such as the Geleen fault, Belgium (Vanneste et al. 2007); the Hope fault (Beauprêtre et al. 2012); and the Wellington fault (McClymont et al. 2008), New Zealand.

We used the pulseEKKO PRO GPR instrument manufactured by Sensor \& Software Inc., including antennas, transmitter, receiver, and control module. We performed the common-offset mode with $50 \mathrm{MHz}$ frequency to collect the GPR data. We acquired 2D GPR sections along 68 survey lines, and 63 of these sections were used to construct a pseudo-3D GPR cube (Fig. 2). Three 2D GPR sections (HMY-01P, HMY-02P, and HMY-03P) were obtained in 2018. The 64-m-long HMY-01P line crossed the Ikeda fault. The other two lines, HMY-02P and HMY03P, were $34 \mathrm{~m}$ and $32 \mathrm{~m}$ long, respectively, parallel to the fault trace. In 2020, we conducted a detailed survey along the fault line to build the pseudo-3D GPR cube. The rectangle size was $20 \mathrm{~m} \times 30 \mathrm{~m}$. We recorded 6120 -m-long inline sections with a $0.5-\mathrm{m}$ spacing and two $30-\mathrm{m}$-long crossline sections at the west and east edges of the rectangle. We also measured 2D sections, HMY-04P and HMY-05P, further north and south of the fault (Fig. 2). Both are $28.4 \mathrm{~m}$ and $32 \mathrm{~m}$ long, accordingly. We also conducted wide-angle measurements or common mid-point (CMP) surveys for subsurface electromagnetic velocity analysis of each 2D and pseudo-3D GPR section. Table 1 shows the data acquisition parameters. The topography along the GPR survey lines was measured using the highprecision GNSS equipment Trimble R10 every $\sim 1$ to $3 \mathrm{~m}$.

We used the RADPRO version 3 software developed by the Korea Institute of Geoscience and Mineral Resources (KIGAM) to process the GPR data. We applied systematic processing steps, including time-zero shift, direct current (DC) removing, dewow filter, bandpass filter, deconvolution, normal move-out (NMO) correction, migration, depth conversion, and topographic correction (Fig. 3). We built velocity models based on the processed CMP ensembles for NMO correction, migration, 

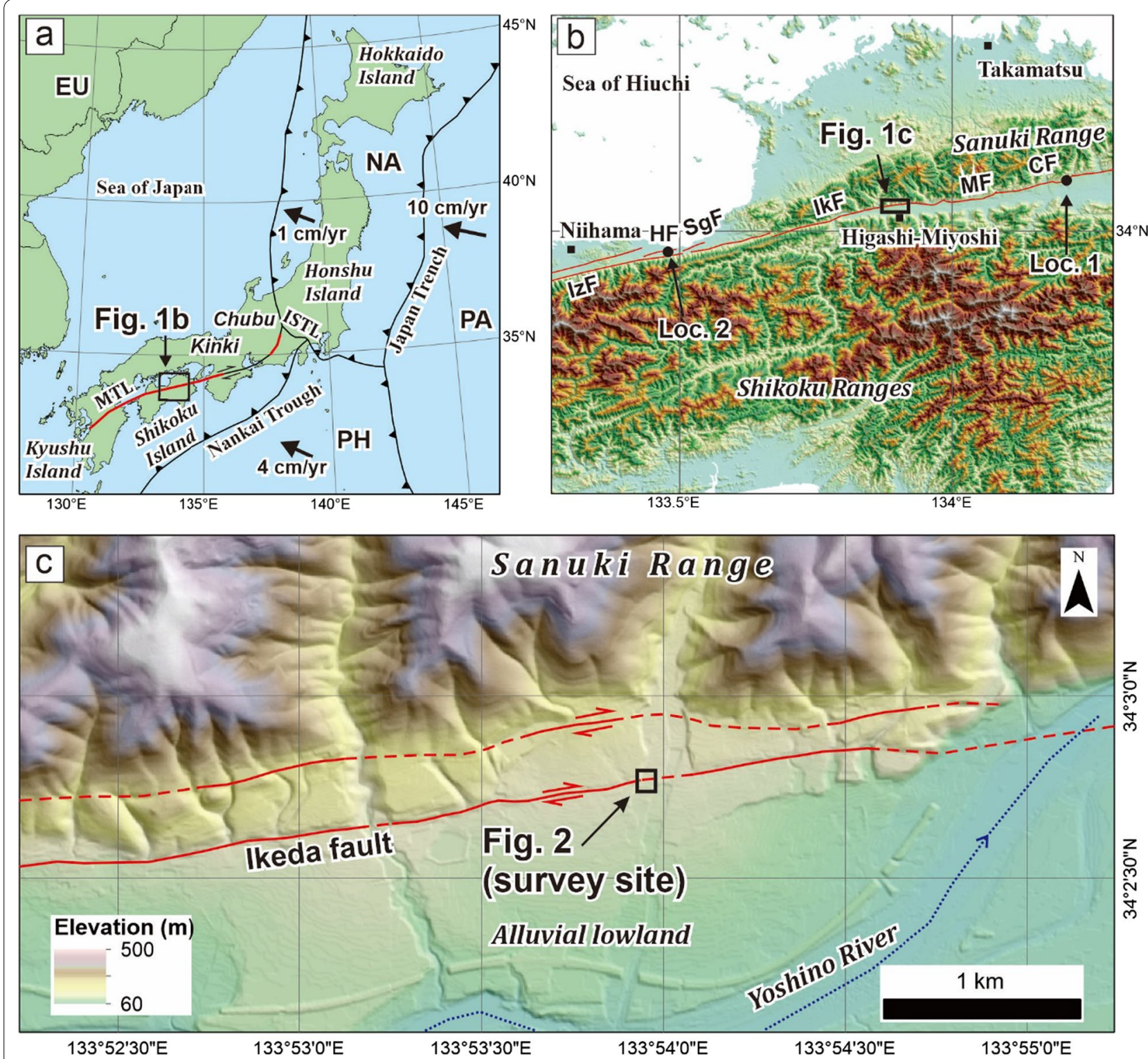

Fig. 1 a Tectonic map of the Japanese Islands. The plate motion vectors are calculated based on DeMets et al. (2010). Thick red lines indicate the active portion of the MTL. EU: Eurasian plate, NA: North American plate, PA: Pacific plate, PH, Philippine Sea plate, MTL: Median Tectonic Line, ISTL: Itoigawa-Shizuoka Tectonic Line. b Active fault traces of the MTL in central to eastern Shikoku (Tsutsumi and Okada 1996). Locs. 1 and 2 denote the surveyed locations of paleochannel offsets by Okada and Tsutsumi (1997) and Goto et al. (2003), respectively. IzF: Ishizuchi fault, HF: Hatano fault, SgF: Sangawa fault, IkF: Ikeda fault, MF: Mino fault, CF: Chichio fault. The topographic base map is made from the SRTM data (https://www2.jpl.nasa. gov/srtm/). c Geomorphology of the area around the survey site. The Ikeda fault trace is from the Active fault database of Japan (https://gbank.gsj. jp/activefault). The topographic base map is made using the 5-m-mesh digital elevation model of the Geospatial Information Authority of Japan

and depth conversion. The velocity of subsurface layers ranged from 0.056 to $0.075 \mathrm{~m} / \mathrm{ns}$ for the $2 \mathrm{D}$ sections. We obtained a single velocity model of $0.064 \mathrm{~m} / \mathrm{ns}$ representing velocity within the pseudo-3D GPR rectangle.

We interpreted the final GPR sections by picking the reflectors manually and evaluating their continuity. On GPR profiles, the active faults are characterized by displaced reflectors or warping reflectors (e.g., Chow et al.
2001; Gross et al. 2002; Kimura et al. 2019; Malik et al. 2007; McClymont et al. 2010). Systematic discontinuities where the vertical offset of reflectors exceeds $1 / 4$ wavelength can be interpreted as faults (Fig. 4a). Discontinuities with depth-differences less than or equal to $1 / 4$ wavelength can be interpreted as faults by combining them with more distinct discontinuities and truncations in their extension zone (Fig. 4b). In addition, we paid 
close attention to identify paleochannel offsets across the fault zone. Several studies imaged paleochannels as trough-like or toward-each-other oppositely dipping reflections (e.g., Beauprêtre et al. 2012; Dujardin et al. 2014; Gross et al. 2002). Gross et al. (2002) showed the comparison between a GPR section and a paleoseismic trench, and their result indicates convincing correlations between paleochannels on trench wall and curved GPR reflections (see Figure 2 in Gross et al. 2002). Based on their interpretation, the base of paleochannel on the GPR section was identified as concave-upward reflectors, lens reflectors, thickened toward center reflectors, and onlap relationships. We used these criteria to recognize the existence of paleochannels on our GPR sections (Fig. 4c, d).

\subsection{D modeling}

We built a 3D model for a selected paleochannel observed in the GPR sections to map its geometry and estimate its displacements. Similar analyses were conducted for the
Emeelt fault, Mongolia (Dujardin et al. 2014); the Alpine fault, New Zealand (McClymont et al. 2010); and the San Andreas fault, USA (Green et al. 2003; Gross et al. 2002). We used the 3D modeling software MOVE developed by Petroleum Experts (Petex) to build a 3D model of the selected paleochannel from the pseudo-3D GPR data. First, we imported the pseudo-3D GPR sections into the software and gave spatial references for data. We manually picked the selected paleochannel's base on every section. After that, we created the 3D grid model and the iso-depth map with $50 \mathrm{~cm}$ resolution.

\section{Site description}

We conducted the GPR survey on the Ikeda fault at Higashi-Miyoshi Town (Fig. 1b). The study area is located at the geomorphic boundary between the Sanuki Range to the north and the alluvial lowland to the south, where the Yoshino River flows eastward (Fig. 1c). The Ikeda fault consists of two fault traces in this area. The northern trace is located at the mountain

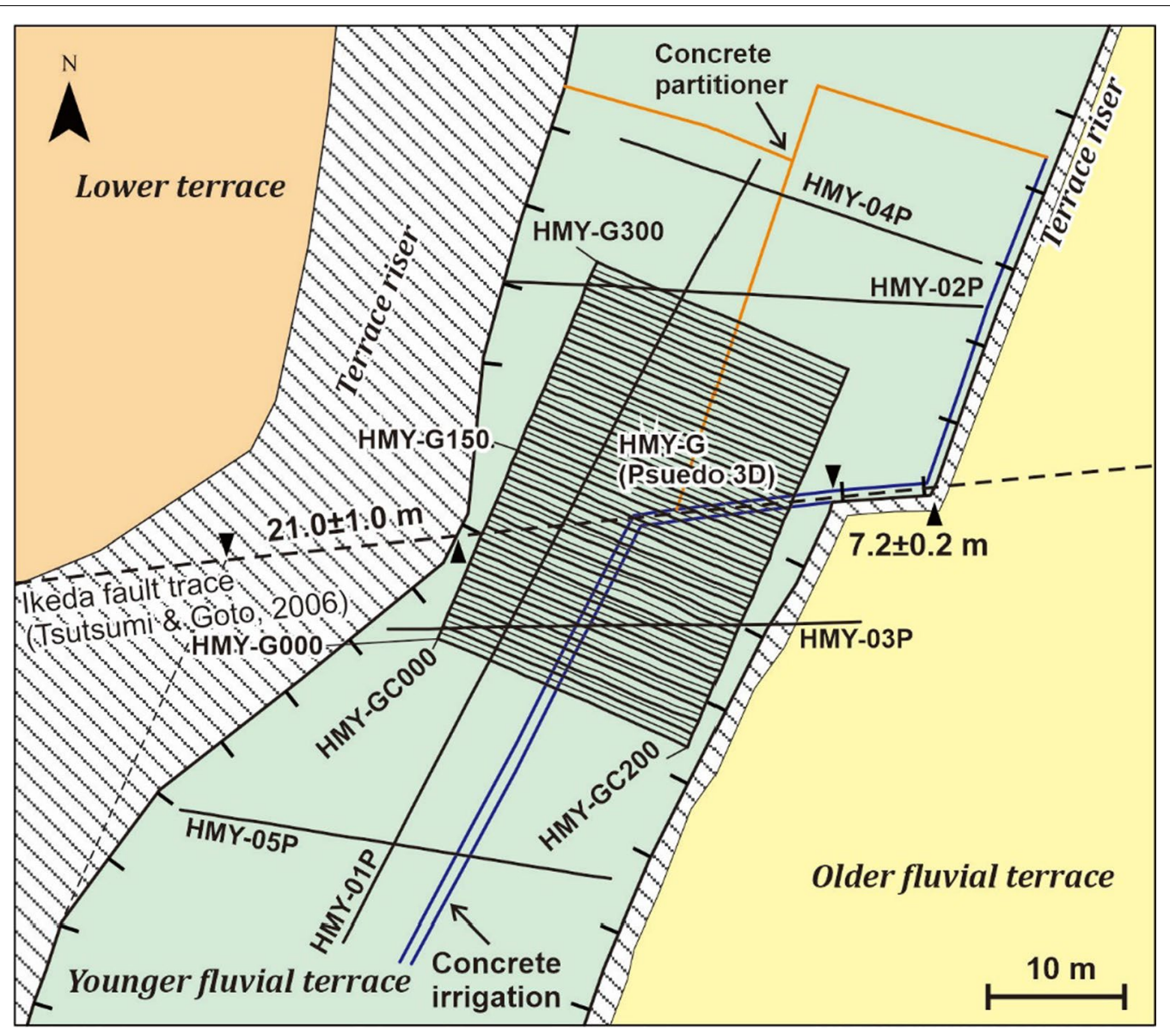

Fig. 2 The survey site map with the 2D and pseudo-3D GPR survey lines. The numbering for the inline sections incrementally increases northward from HMY-G000 to HMY-G300 with a step of 5. The crossline sections consist of HMY-GC000 and HMY-GC200. The Ikeda fault trace, terraces, and two offset terrace risers are from Tsutsumi and Goto (2006) 
front, while the southern trace is marked by fault scarps down to the south, cutting the fluvial terraces (Fig. 1c). Our GPR survey site was on the southern fault line, where two terrace risers are offset right-laterally (Fig. 2). The geomorphology of the site consists of two levels of fluvial terraces (younger and older) and the lower terrace (Tsutsumi and Goto 2006) (Fig. 2). The younger fluvial terrace is a strath terrace downcutting the older fluvial terrace at $\sim 1 \mathrm{~m}$. The lower terrace is the oldest and $\sim 15 \mathrm{~m}$ above the younger fluvial terrace. A previous study by Saito et al. (1997) indicates that the lower terrace along the MTL in western Kinki district is correlated with the last glacial maximum at 26-29 Kya. Tsutsumi and Goto (2006) interpreted that the terrace risers separating the three terrace surfaces are offset right-laterally by the Ikeda fault (Fig. 2). The offset amount of the west-facing younger terrace riser is $\sim 7 \mathrm{~m}$, while the offset of the east-facing older terrace riser is $\sim 21 \mathrm{~m}$. The surveyed area is on the younger fluvial terrace between the two terrace risers, and it has been modified as a rice paddy field. The topography is almost flat, and the difference between the minimum and maximum elevations is less than $0.5 \mathrm{~m}$. There are concrete partitioner and concreate irrigation within the paddy field. The concrete structures at the surface in the study site were taken into consideration during interpretation because they disrupt the GPR reflections.

\section{Results}

In this section, the description of the faults and paleochannels use the names that represent their correlations. However, the correlations of the faults and paleochannels are later explained in the discussion section.

\subsection{D GPR}

\subsubsection{HMY-01P}

The HMY-01P line trended NNE and crossed the Ikeda fault (Fig. 2). The depth-converted section and its interpretation are shown in Fig. 5. The section shows prominent and parallel reflectors at a depth of 0-2.6 m, while the deeper part is characterized by subtle reflectors (Fig. 5a). The reflectors at the shallower part are generally horizontal and in places displaced. Between horizontal distance (HD) $7 \mathrm{~m}$ and $9 \mathrm{~m}$, these reflectors are slightly downthrown from the adjacent reflectors by the F5 fault (Fig. 5a, b). The discontinuities of the horizontal reflectors mark the F4 and F2 faults at HD $18 \mathrm{~m}$ and $29 \mathrm{~m}$, respectively. The $\mathrm{F} 4$ fault truncates the north-dipping reflectors at a depth of $1.6 \mathrm{~m}$. Concave-upward reflectors are observed at HD 33-38 m. We interpreted a reflector with a limited extent (lens reflector) at a depth of $1.6 \mathrm{~m}$ between HD 33 and $38 \mathrm{~m}$, which is underlain by a concave-upward reflector as a paleochannel. Immediately north of the paleochannel, the F1 fault is identified by discontinuities of the reflectors down to the south. This fault also marks the dip change of the reflectors, from horizontal in the north to south dip to the south.

\subsubsection{HMY-04P and 02P}

The HMY-04P and 02P lines are north of and sub-parallel to the Ikeda fault (Fig. 2). Figure 6 shows depth-converted sections and their interpretations.

On the HMY-04P section, we can identify prominent and continuous reflectors down to $2 \mathrm{~m}$ depth (Fig. 6a). Between HD $0 \mathrm{~m}$ and $13 \mathrm{~m}$, the reflectors are continuous and curved. We identified the paleochannel A based on a lens reflector between HD $3 \mathrm{~m}$ and $9 \mathrm{~m}$ at a depth of $\sim 0.8 \mathrm{~m}$, underlain by concave-upward reflectors and overlain by a horizontal reflector (Fig. 6a, b). The

Table 1 GPR data acquisition parameters

\begin{tabular}{|c|c|c|c|}
\hline & 2D profiles & Pseudo-3D rectangles & Common mid-point (CMP) \\
\hline Instrument & \multicolumn{3}{|c|}{ pulseEKKO PRO (Sensors \& Software Inc.) } \\
\hline Frequency & $50 \mathrm{MHz}$ & $50 \mathrm{MHz}$ & $50 \mathrm{MHz}$ \\
\hline No. of SPs ${ }^{a} /$ Length $(\mathrm{m})$ & $\begin{array}{l}\text { 161/64 (HMY-01P) } \\
\text { 86/34 (HMY-02P) } \\
81 / 32 \text { (HMY-03P) } \\
\text { 72/28.4 (HMY-04P) } \\
81 / 32 \text { (HMY-05P) }\end{array}$ & $\begin{array}{l}\text { 41/20 (61-inline profiles) } \\
61 / 30 \text { (2-crossline profiles) }\end{array}$ & 99 traces/1 CMP ensemble \\
\hline$T x-R x^{b}$ & $1.0 \mathrm{~m}$ & $1.0 \mathrm{~m}$ & $0.2-10 \mathrm{~m}$ \\
\hline SP interval & $0.4 \mathrm{~m}$ & $0.5 \mathrm{~m}$ & 0.1-m offset increment \\
\hline No. of scans/1 SP & 64 & 64 & 64 \\
\hline No. of samples & 250 & 250 & 250 \\
\hline Sampling interval & $1.6 \mathrm{~ns}$ & $1.6 \mathrm{~ns}$ & $1.6 \mathrm{~ns}$ \\
\hline
\end{tabular}

a SP: scan point

${ }^{\mathrm{b}} \mathrm{Tx}-\mathrm{Rx}$ : offset between transmitter and receiver 


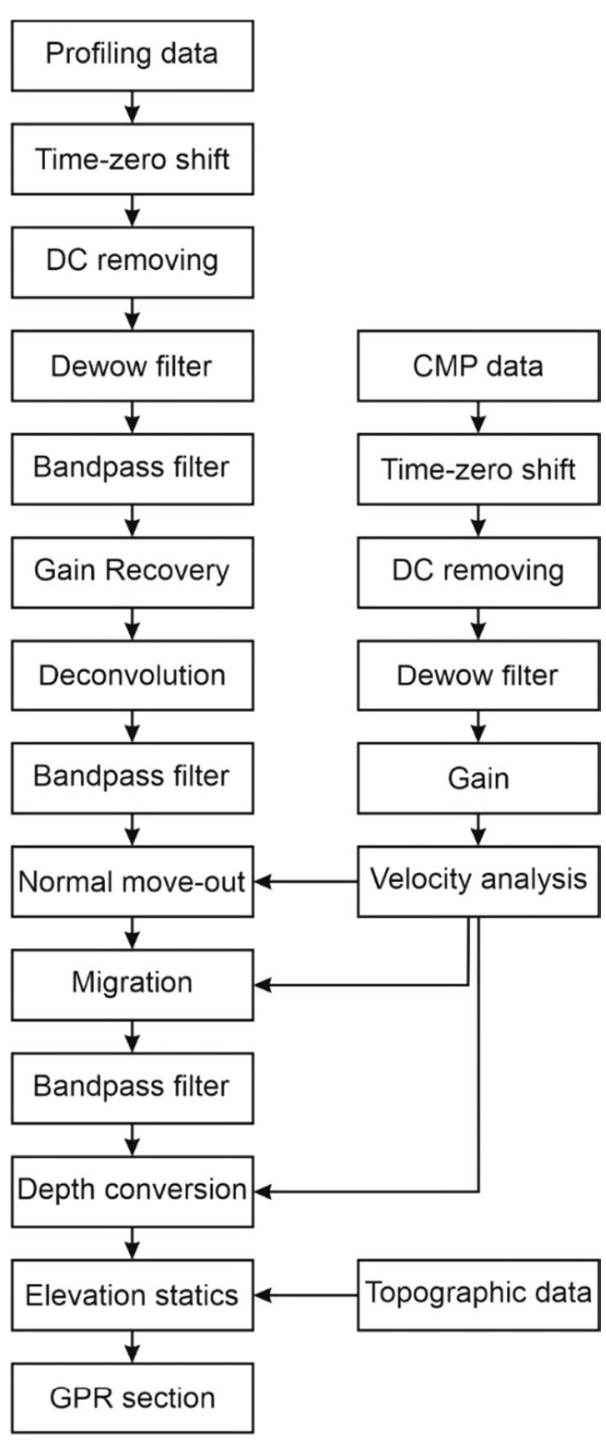

Fig. 3 Flowchart of GPR data processing

concrete structure at the surface appears to disrupt the reflections at HD $12 \mathrm{~m}$. From HD $13 \mathrm{~m}$ to the eastern end, the section shows parallel and horizontal reflectors. Although the reflections are faint at the deeper part of the section, the paleochannel $\mathrm{B}$ is clearly recognized as a curved reflector and a thickened reflector at HD 17-24 m and a depth of $\sim 2.8 \mathrm{~m}$ (Fig. 6a, b).

Similar features characterize the HMY-02P section. The upper $\sim 2-\mathrm{m}$ part shows strong and mostly continuous reflectors, compared to subtle reflectors below (Fig. 6c). Reflectors at the shallow eastern part are horizontal, while the reflectors are gently curved in the west. A parallel concave-upward reflector indicates the paleochannel A between HD 7 and $17 \mathrm{~m}$ at $\sim 0.8 \mathrm{~m}$ depth (Fig. 6c, d). A discontinuous reflector onlaps the western edge of the concave-upward reflector at HD $7 \mathrm{~m}$. The discontinuity at HD $17 \mathrm{~m}$ is considered related to the concrete structure at the surface. The weak concave-upward reflectors mark the paleochannel $B$ at HD $24-33 \mathrm{~m}$ and a depth of $\sim 2.8 \mathrm{~m}$. Within the trough of the paleochannel $\mathrm{B}$, the reflectors are thickened toward the center (Fig. 6c, d).

\subsubsection{HMY-03P and 05P}

The HMY-03P and 05P sections are sub-parallel to and south of the Ikeda fault (Fig. 2). Figure 7 shows the depthconverted sections and their interpretations.

On the HMY-03P section, the reflectors at the shallower part are generally horizontal, except those at HD 3-15 m that dip to the west. Slight disruption at HD 15 is related to the concrete structure at the surface. A concave-upward reflector marks the paleochannel $\mathrm{A}$ at a depth of $\sim 0.6 \mathrm{~m}$ (Fig. 7a, b). Two reflectors are truncated at the base of the paleochannel A. The paleochannel B is identified between HD $0 \mathrm{~m}$ and $7 \mathrm{~m}$ at a depth of $\sim 2.2 \mathrm{~m}$ based on a weak concave-upward reflector (Fig. 7a, b). Prominent westward dipping reflectors are recognized above the eastern flank, and a horizontal reflector onlaps the western flank of the Paleochannel B.

Continuous reflectors characterize the shallow part of the HMY-05P section (Fig. 7c). The section shows horizontal and parallel reflectors from HD $10 \mathrm{~m}$ eastward with a slight incline at HD $20-23 \mathrm{~m}$, plausibly due to the concrete structure at the surface. We identified the paleochannels A and B on the HMY-05P section. A concaveupward reflector at the shallower part that onlaps the reflector below marks the paleochannel A at HD 1-8 m (Fig. 7c, d). Just beneath the paleochannel A, the base of the paleochannel $\mathrm{B}$ is characterized by a weak concaveupward reflector at a depth of $\sim 2.4 \mathrm{~m}$ (Fig. $7 \mathrm{c}, \mathrm{d}$ ). Westward and eastward dipping reflectors are observed at the eastern and western flanks, respectively. There is a lens reflection within the paleochannel B.

\subsection{Pseudo-3D GPR}

\subsubsection{Crossline sections}

We acquired crossline sections on the west and east ends of the pseudo-3D GPR rectangle (HMY-GC000 and HMY-GC200 in Fig. 2). These sections crossed the Ikeda fault and were almost parallel to the HMY-01P line. Figure 8 displays the depth-converted crossline sections and their interpretations.

Strong reflectors with some discontinuities dominate the shallow part of the HMY-GC000 section (Fig. 8a). The reflectors at HD 1-8 m gently dip to the south. We interpret the down-to-the-north displacement at 

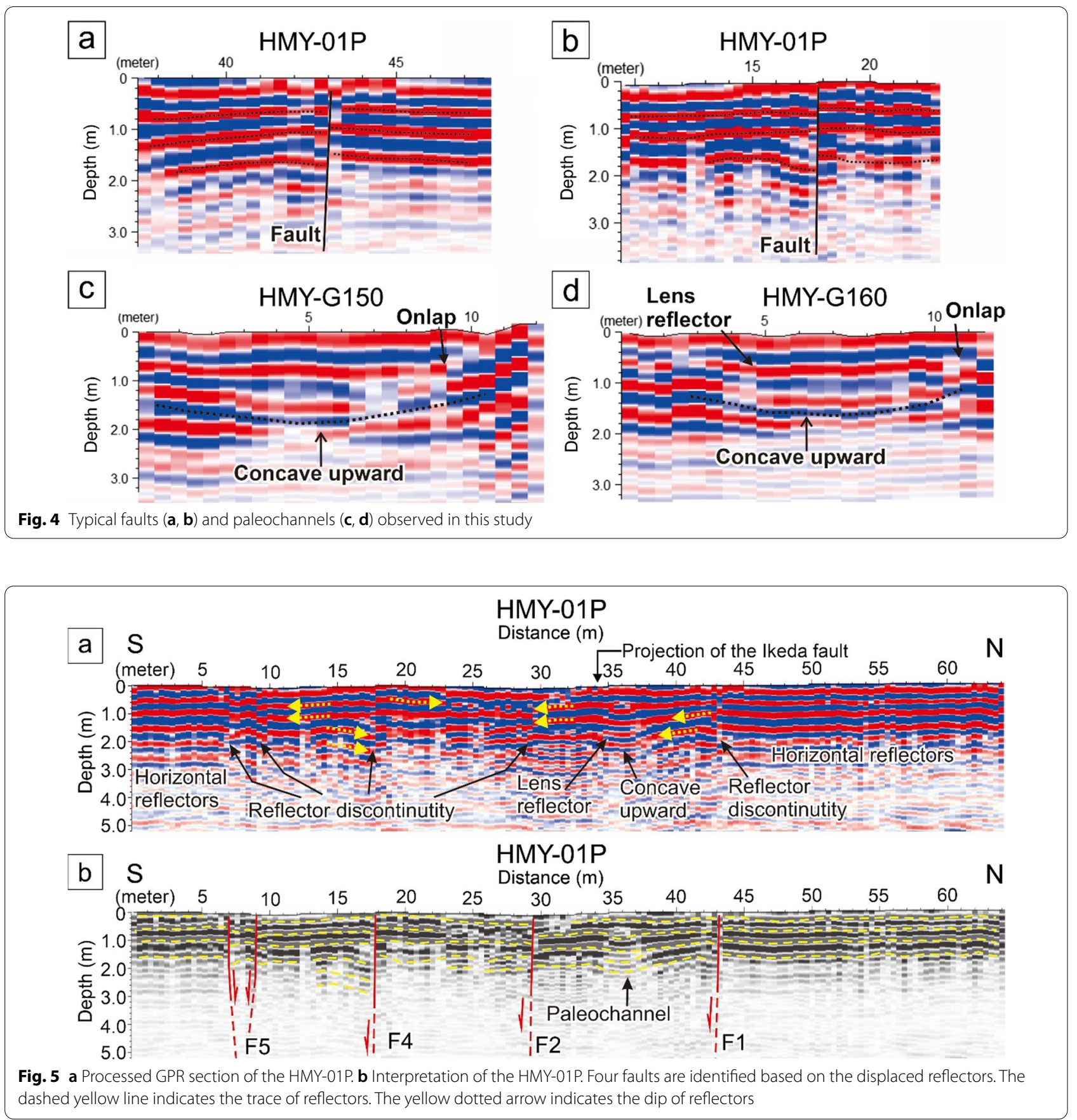

HD $1 \mathrm{~m}$ as the F3 fault. We identify displaced reflectors between HD 8-17 m. The F2 fault is identified at HD $8 \mathrm{~m}$ as reflectors are displaced down to the south (Fig. 8a, b). North of the F2 fault, the F2a cuts the north-dipping reflectors down to the south at HD $10 \mathrm{~m}$, while the F2b fault cuts reflectors down to the north (Fig. 8a, b). The F1 fault marks the dip changes of distinct reflectors as the dip of south-dipping reflectors becomes shallower south of the F1 fault. Parallel horizontal reflectors characterize the section from HD 19 to the northern end.

On the HMY-GC200 section, continuous prominent reflectors occupy the upper part of the section (Fig. 8c). The reflectors at HD 0-19 $\mathrm{m}$ are primarily horizontal. The concrete structure at the surface affects the reflection at around HD $20 \mathrm{~m}$. There is a slight offset reflectors displacement at HD $5 \mathrm{~m}$ which we identified as the F2 fault. The reflectors between HD $20 \mathrm{~m}$ and $25 \mathrm{~m}$ 


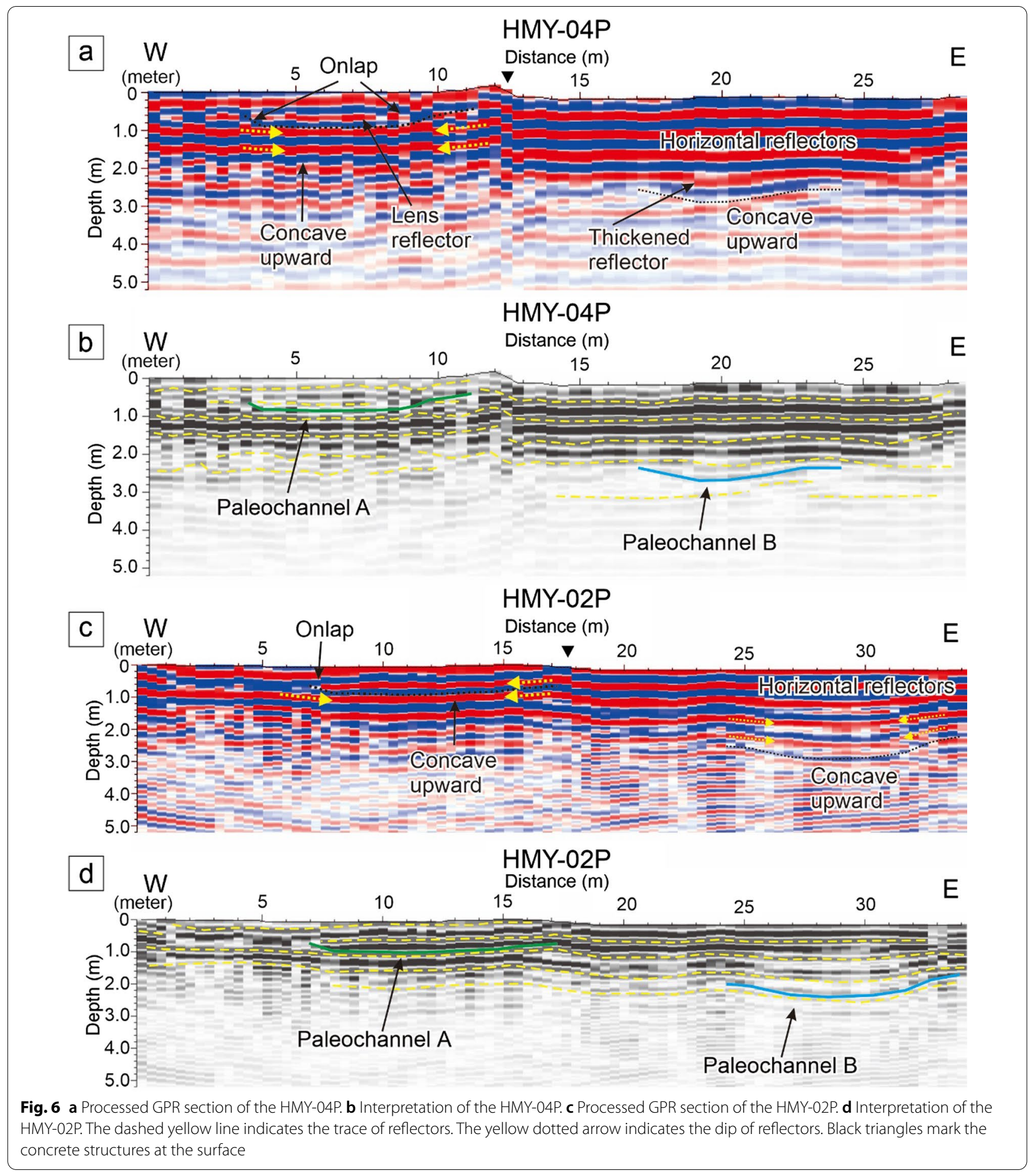

gently dip to the north, while those further north are almost horizontal. We interpret this dip change as the F1 fault (Fig. 8c, d).

\subsubsection{Inline sections}

Figure 9 shows five selected depth-converted inline sections of the pseudo-3D GPR that trended northwest, oblique to the Ikeda fault (Fig. 2). The reflections are prominent and continuous down to a depth of $\sim 3$-m of 
the inline sections. Parallel horizontal reflectors occupy the eastern part of the sections. Each section's central and western portions are characterized by concaveupward reflectors that underlie some lens reflectors. We recognized two paleochannels, the paleochannels $\mathrm{A}$ and $\mathrm{C}$, based on concave-upward reflectors, lens reflectors, onlapping reflectors, and thickening-toward-center reflectors (Fig. 9). The paleochannel $\mathrm{A}$ is observed on all inline sections at a depth of 0.6-1.4 m, and it appears deflected to the right. The paleochannel $\mathrm{C}$ is located just west of the paleochannel $\mathrm{A}$ at a depth of $0.6-1.4 \mathrm{~m}$ and is

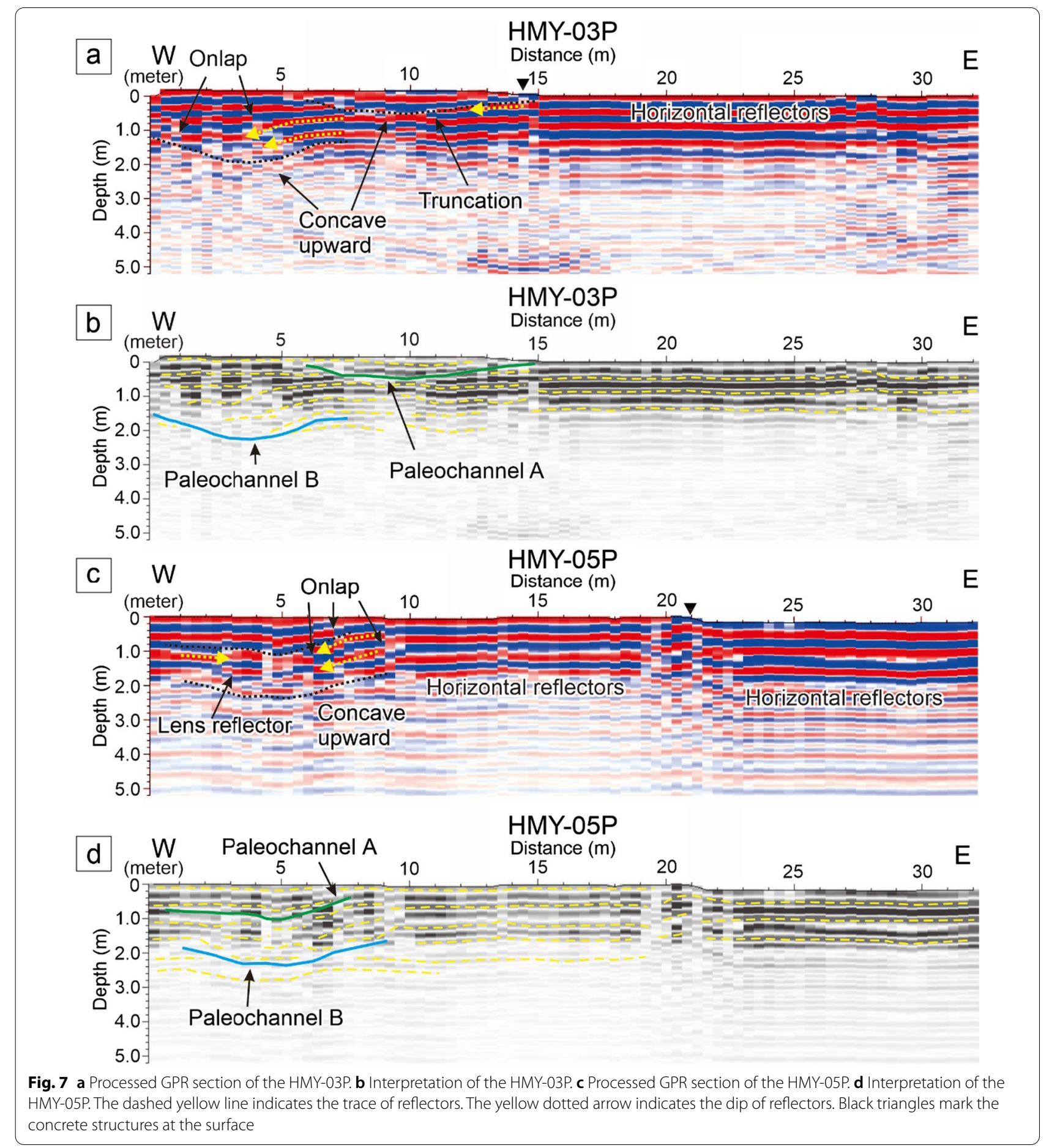


observed only in the northwestern part of the pseudo-3D GPR rectangle.

\section{Discussions}

\subsection{Subsurface displacements of buried paleochannels}

All interpretations and correlations of paleochannels and faults are plotted in Fig. 10. The F1 fault observed in the HMY-01P, HMY-GC000, and HMY-GC200 sections can be correlated because its traces on GPR sections show similar down to the south vertical slips. The F1 fault correlation indicates an east-west strike and coincides with the paleochannel A's offset (Fig. 10b). The position of the F1 fault is $5-10 \mathrm{~m}$ north of the projected fault trace by Tsutsumi and Goto (2006), based on offset terrace risers.
The F2 fault in the HMY-01P section is correlated with the F2 fault in the HMY-GC000 and HMY-GC200 sections as they are aligned and record the same vertical motion down to the south. The F2 fault correlation indicates a northwest strike oblique to the F1 fault (Fig. 10b). There are three other faults (F2a, F2b, and F3) observed only in the HMY-GC000 section. Further south, the F4 and F5 faults appear only in the HMY-01P section.

The paleochannel A appears in all GPR sections, except the HMY-01P section (Fig. 10a). This paleochannel is correlated between the GPR sections based on the similarity of the reflection features and depths. The correlation of the paleochannel A shows north-south to southsouthwest directions within the pseudo-3D GPR data
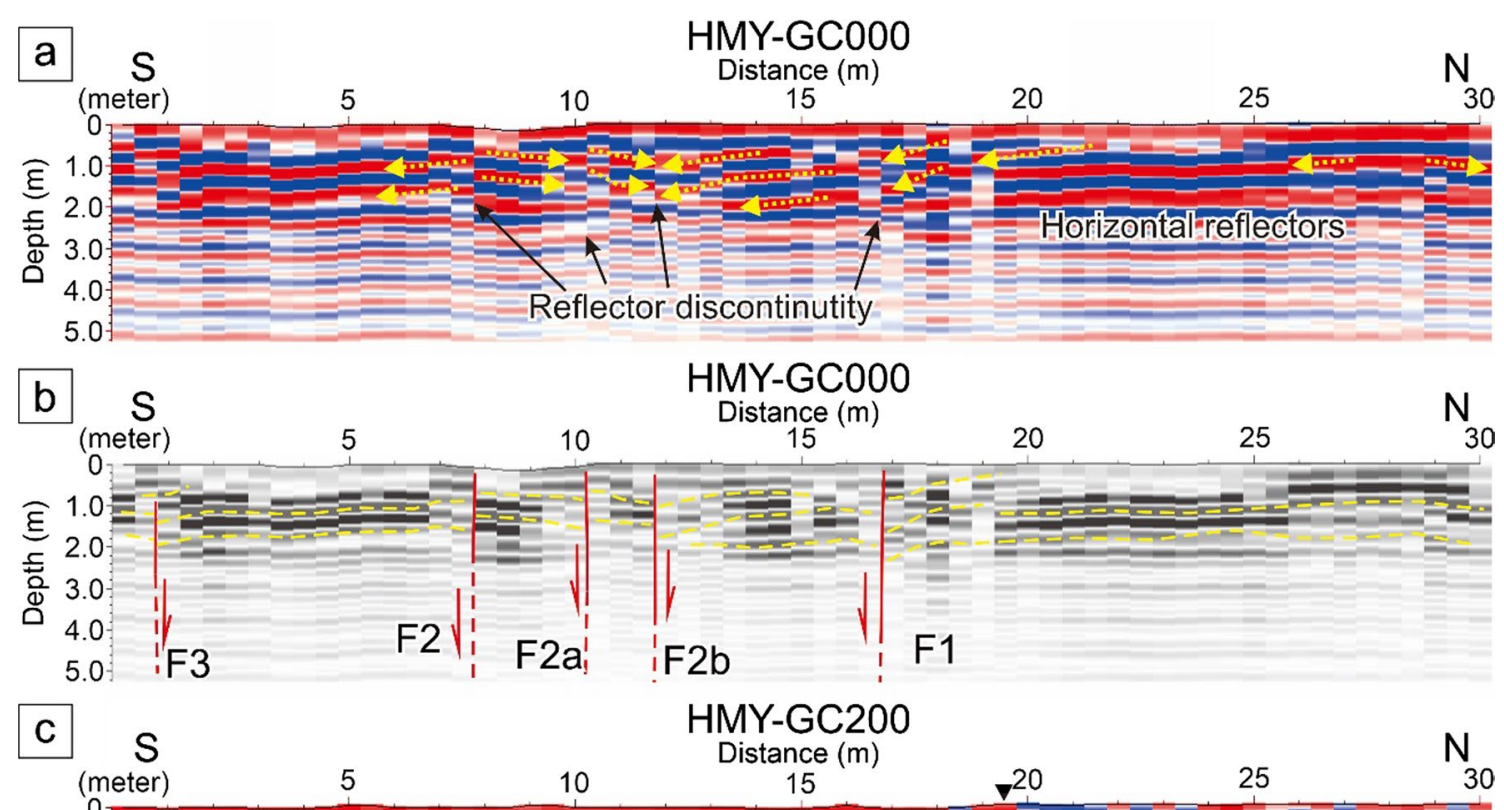

F1
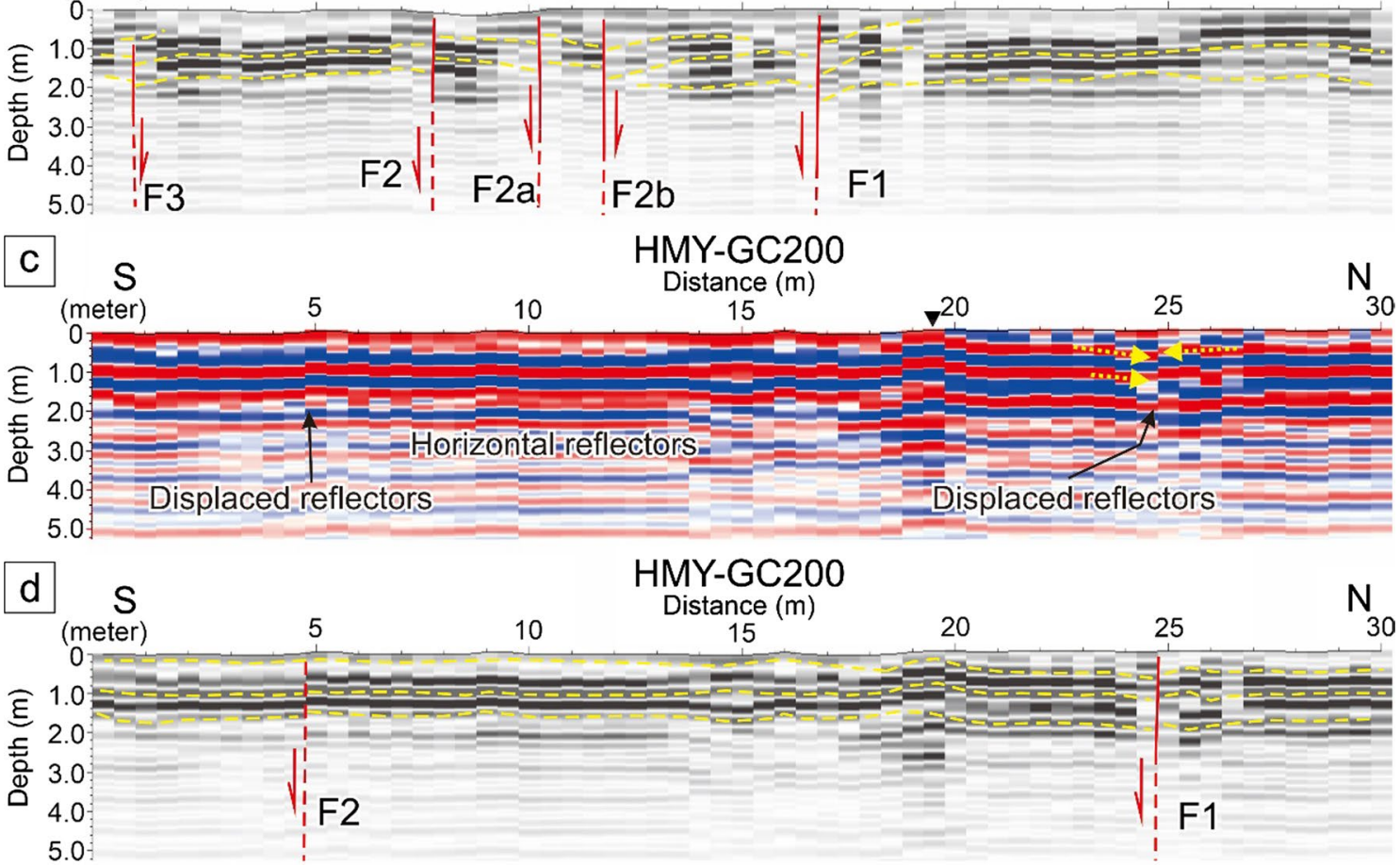

Fig. 8 a Processed GPR sections of the HMY-GC000. b Interpretation of the HMY-GC000. c Processed GPR section of the HMY-GC200. d Interpretation of the HMY-GC200. The dashed yellow line indicates the trace of reflectors. The yellow dotted arrow indicates the dip of reflectors. Black triangles mark the concrete structures at the surface 
(Fig. 10b). The paleochannel A is right-laterally offset by the F1 fault. The paleochannel B in the HMY-04P and HMY-02P sections shows similar features of thickened reflectors. To the south, the paleochannel B in the HMY03P and HMY-05P sections is characterized by weak concave-upward reflectors filled by horizontal or lens reflectors. However, the similarity of the depth suggests that this paleochannel might be the same age and can be correlated. The paleochannel B is considered the oldest as it is located deepest. The paleochannel B appears to be deflected by the F1 fault and offset more than the paleochannel $\mathrm{A}$, but we cannot estimate the offset amount since it does not appear in the pseudo-3D GPR data. The absence of the paleochannel $B$ on the pseudo3D GPR could be explained for two reasons. First, most portions of the paleochannel B may be outside the coverage of the pseudo-3D GPR data. Second, the attenuation of the electromagnetic wave during the pseudo-3D survey may have been larger due to the change of the conditions of the survey site, such as volumetric water content. The paleochannel $\mathrm{C}$ is only observed at a limited portion within the pseudo-3D GPR data. The paleochannel $\mathrm{C}$ is consistently located just west of and at a similar depth with the paleochannel $\mathrm{A}$. The paleochannel $\mathrm{C}$ is interpreted as older than the paleochannel $\mathrm{A}$, and its southern portion might have been eroded because of the development of the paleochannel A.

We selected the paleochannel A for 3D modeling (Additional file 1) because it appears in all inline pseudo3D GPR sections and is displaced by the faults. We created the iso-depth map of the channel's base (Fig. 11a). The iso-depth map depicts that the paleochannel's base generally deepens southward, consistent with the flow direction of the paleochannel. However, an abrupt change in depth of the paleochannel A's base and rightlateral deflection across the F1 fault suggests that the fault has displaced the channel. We calculated the rightlateral offset of the paleochannel A using the eastern and western edges as piercing points (Fig. 11a). The backprojection of the paleochannel A indicates that the paleochannel is right-laterally offset at $3.5 \pm 0.7 \mathrm{~m}$ (Fig. 11b). We estimated the vertical displacement on the F1 fault using the paleochannel A's base as reference points. A longitudinal profile of the paleochannel's base shows an elevation change of $\sim 0.5 \mathrm{~m}$ down to the south that we interpret as vertical displacement (Fig. 11c). The ratio of vertical displacement to horizontal offset on the F1 fault is calculated at $14 \%$. The predominant horizontal paleochannel offsets are consistent with the tectonic geomorphic features of the MTL (Okada 1980). South of the F1

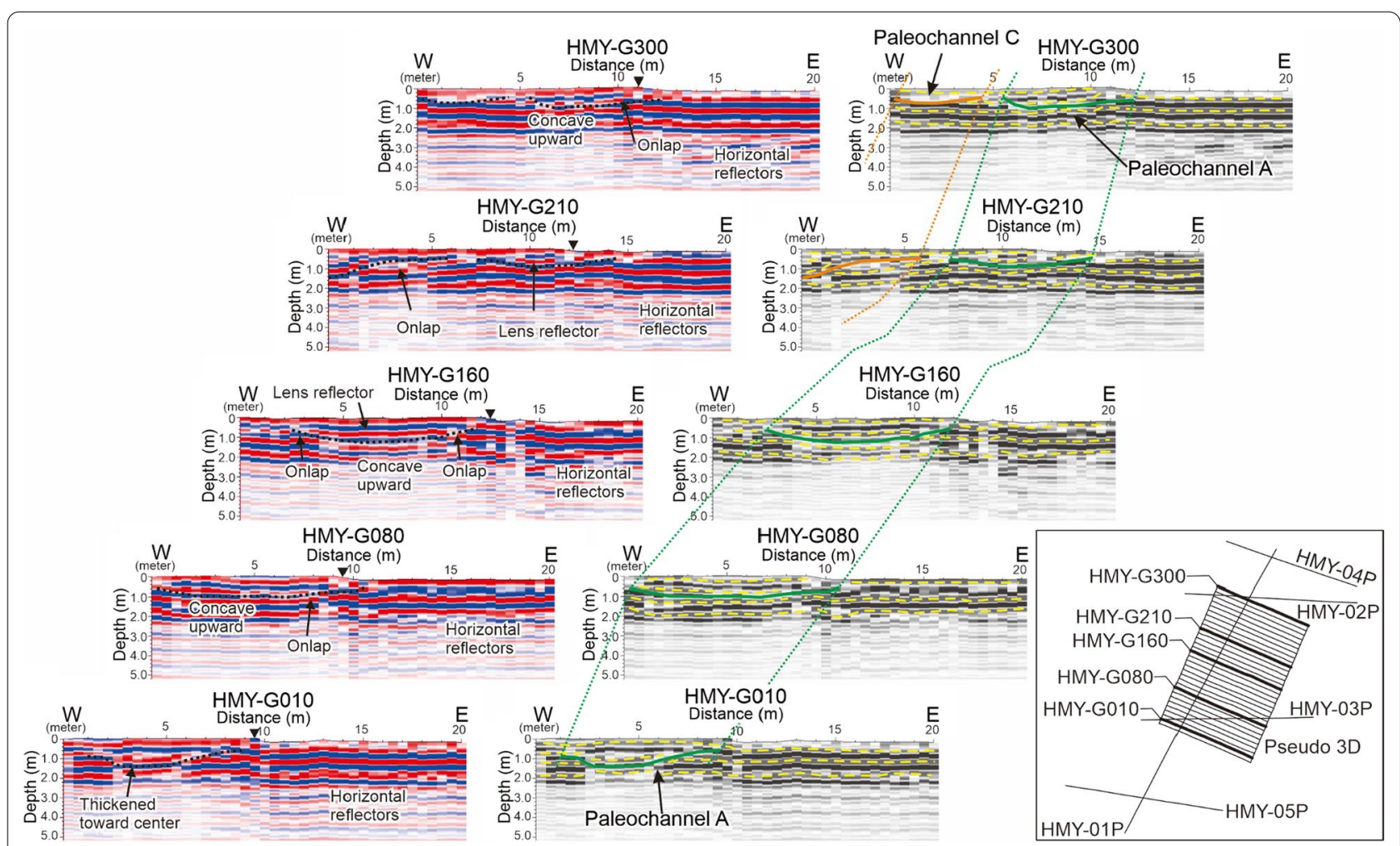

Fig. 9 Selected processed inline GPR sections from the pseudo-3D GPR data and their interpretations. Two paleochannels are identified within the pseudo-3D GPR data. The dashed yellow line indicates the trace of reflectors. Black triangles mark the concrete structures at the surface 
fault, another deformation of the base of paleochannel is identified as slight uplift, where the base is $\sim 0.3 \mathrm{~m}$ higher than the adjacent area (Fig. 11a). This deformation is interpreted to be caused by the F2, F2a, and F2b faults.

The F1 fault appears to be the main structure on the GPR sections. However, extending the F1 fault to the west and east would not match the geomorphology of the site. The F1 fault is not aligned with the offset terrace risers. We propose that the F1, F2, F2a, and F2b are subsidiary faults in a strike-slip fault zone. Strike-slip faults are commonly represented by various subsidiary structures within sedimentary layers (Sylvester 1988) (inset of Fig. 10b). The characteristics of these structures are determined by their orientations to the main fault. The Riedel shears (R)/synthetic faults develop at an angle of about $10-20^{\circ}$, clockwise from the main fault, and have the same slip sense as the main fault. The normal faults (NF) trend roughly $45^{\circ}$, clockwise from the main fault, and often form in an en echelon arrangement. The projected fault trace by Tsutsumi and Goto (2006) is considered as the principal displacement zone (PDZ) of the Ikeda fault because it agrees with the geomorphic offsets. The PDZ may be located deeper and is absent at the shallow subsurface, so it could not be imaged on the GPR sections. The Ikeda fault is expressed by the subsidiary faults at the near-surface in our survey site. We measured that the F1 fault and the PDZ make an angle of $\sim 10^{\circ}$, and the F1 fault is predominantly right-lateral strike-slip fault. Thus, we interpreted the F1 fault as a Riedel shear/synthetic fault of the Ikeda fault, and the offset on the PDZ is calculated at $\sim 3.8 \mathrm{~m}$ (Fig. 11d). The F2, F2a, F2b faults are oriented at about $35^{\circ}$ from the PDZ, and they are obviously observed as normal faults on the GPR sections.

A compilation of trenching data by Morino and Okada (2002) suggested that most segments of the MTL in Shikoku ruptured in the sixteenth century. Historical records indicated that the 1596 Keicho-Fushimi earthquake caused considerable damage to the Kinki area northeast of Shikoku. A trenching study by Tsutsumi and Okada (1996) documented that the Chichio fault in eastern Shikoku ruptured after the sixteenth century AD. They proposed that the MTL in eastern Shikoku may have moved during the 1596 Keicho-Fushimi earthquake together with the faults in the Kinki area. The $\sim 3.5-\mathrm{m}$ right-lateral and $\sim 0.5 \mathrm{~m}$ vertical displacements of the paleochannel A appear to be related to the most recent surface-rupturing earthquake on the Ikeda fault. The F1 fault might extend further east and deform the terrace riser identified by the Tsutsumi and Goto (2006) east of the survey site (Fig. 10b). Consequently, the $\sim 7$-m rightlateral offset of this terrace riser may be due to at least two surface-rupturing earthquakes. The F2 fault south of the F1 fault might have caused the localized deformation of the base of the paleochannel A (Fig. 11a). This deformation was plausibly related to the coseismic rupture of the recent large earthquake off the main F1 fault.

Because the study site has been artificially modified as a paddy field, the geomorphic features due to the most recent ground-rupturing earthquake might have been removed. Besides the terrace riser offsets identified by Tsutsumi and Goto (2006), we were able to detect the subsurface geological features such as faults and paleochannels using the GPR method. A detailed survey using the pseudo-3D technique allowed us to map buried paleochannels. Furthermore, we were able to identify and measure the offset paleochannel due to the most recent earthquake on the Ikeda fault of the MTL.

\subsection{Right-lateral offsets related to the most recent earthquakes on the MTL in Shikoku}

Considering the right-lateral slip rate of the MTL in Shikoku ranges $5-10 \mathrm{~mm} / \mathrm{yr}$ with the recurrence interval of surface-rupturing earthquakes of 1000-3000 years (Tsutsumi and Okada 1996), the minimum average slip is $5 \mathrm{~m}$ for an earthquake on the MTL in Shikoku. In some places on the MTL in Shikoku, the horizontal and vertical displacements due to the most recent surface-rupturing earthquake were convincingly measured. Okada and Tsutsumi (1997) documented $\sim 6$ to $7 \mathrm{~m}$ right-lateral and $\sim 1 \mathrm{~m}$ down to the south vertical displacements due to the last earthquake in the sixteenth century on the Chichio fault based on a paleochannel offset exposed during an archeological excavation at Loc. 1 (Fig. 1b). Goto et al. (2003) identified $\sim 2.5 \mathrm{~m}$ right-lateral offset of a paleochannel with $0.3-0.5 \mathrm{~m}$ vertical displacement down to the south on the Hatano fault at Loc. 2 (Fig. 1b), related to a single faulting activity between 1520 and $1660 \mathrm{AD}$. The survey site in this study is located between Locs. 1 and 2. Although the vertical and horizontal displacements were calculated on the Riedel shear/synthetic fault in this study, these displacements are comparable to the offsets related to the most recent earthquake on the MTL in Shikoku. However, we could not determine that all offsets at the three sites occurred during a single earthquake, or there might have been more than one earthquake during the sixteenth century that ruptured

(See figure on next page.)

Fig. 10 a Extent of the paleochannels and faults observed on the GPR sections. $\mathbf{b}$ Correlation of the faults and paleochannels. The right-lateral offset of the paleochannel A is associated with the F1. The Ikeda fault trace and two offset terrace risers are from Tsutsumi and Goto (2006). Inset shows subsidiary structures associated with a strike-slip fault (modified after Sylvester 1988). PDZ: principal displacement zone, R: synthetic shears, R': antithetic shear, P: secondary synthetic shear, TF: thrust fault, NF: normal fault 

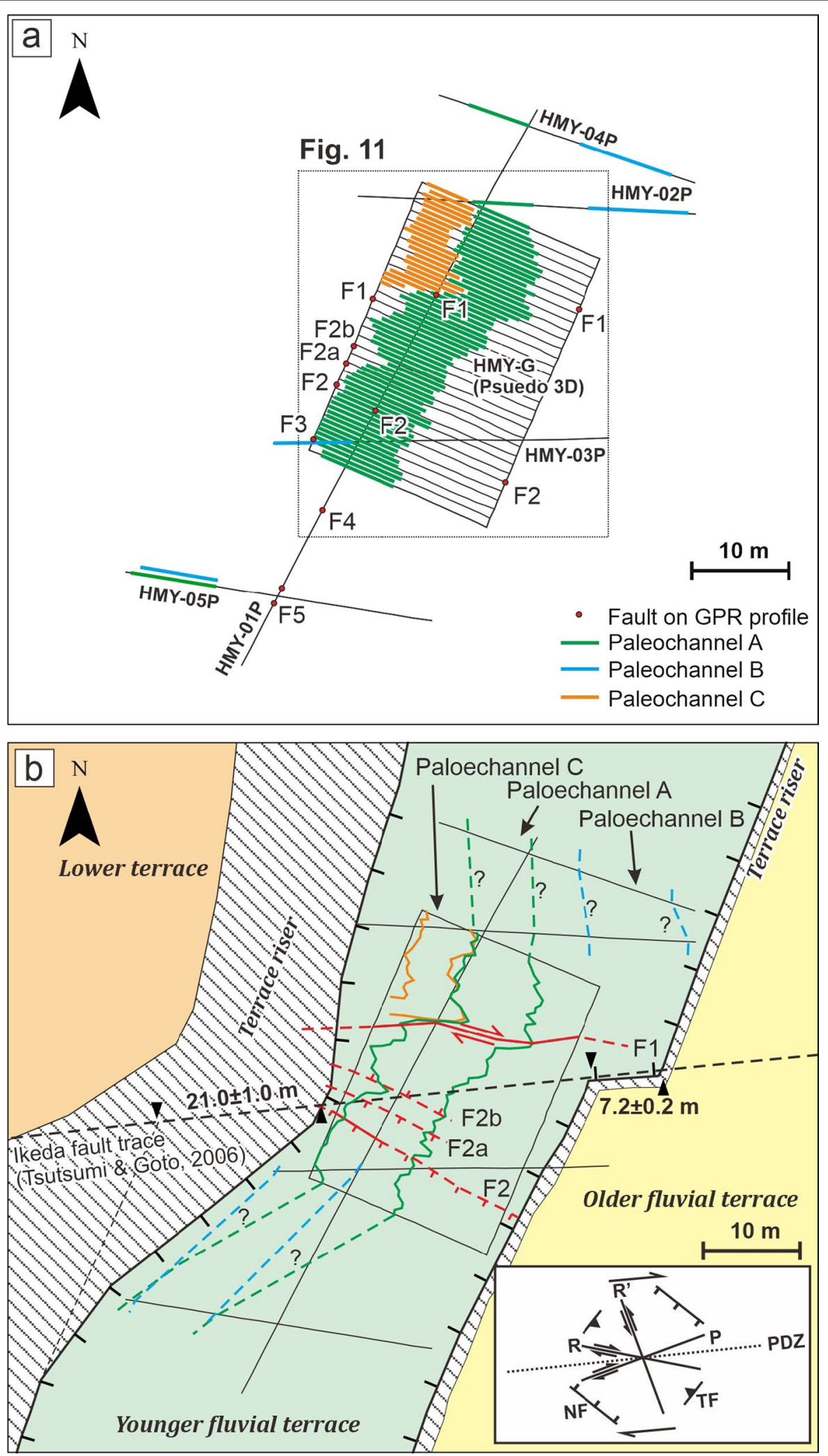

Fig. 10 (See legend on previous page.) 

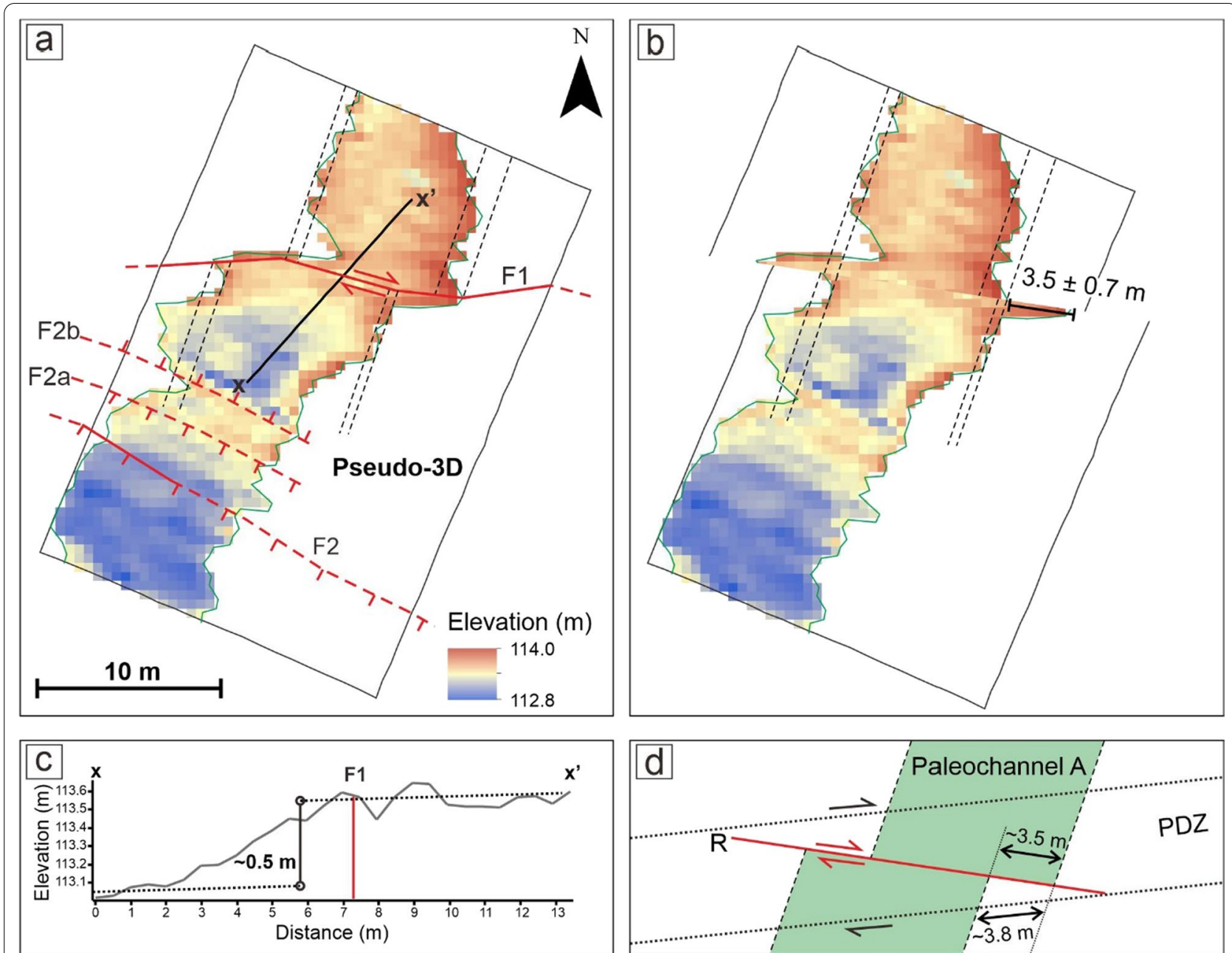

Fig. 11 a lso-depth map of the paleochannel A. Dashed black lines mark the paleochannel's edges, considered as piercing points. b Back-projection of the paleochannel A. c Longitudinal profile of the base of the paleochannel A across the F1 fault. Dotted black lines indicate the reference for the vertical displacement calculation. $\mathbf{d}$ Schematic diagram showing the estimation of the horizontal offset amount on the PDZ

the MTL in Shikoku. If those right-lateral offsets from three surveyed locations were caused by a single earthquake, the amount of horizontal slip might decrease westward from the Chichio fault to the Ikeda fault, or the horizontal offset on the Chichio fault might be partitioned because the Ikeda fault consists of two fault traces around the survey site (Fig. 1c).

\section{Conclusions}

We conducted the 2D and pseudo-3D GPR surveys across the Ikeda fault of the MTL in southwest Japan. The processed GPR sections depict several fault traces and three paleochannels. We were able to trace the paleochannel A in the 2D and pseudo-3D GPR data. A 3D modeling illustrates $\sim 3.5$ - $\mathrm{m}$ right-lateral and $\sim 0.5$ - $\mathrm{m}$ vertical offsets of the paleochannel by the F1 fault with a vertical-tohorizontal displacements ratio of $14 \%$. The offset of the paleochannel may result from the most recent surfacerupturing earthquake, but its timing and correlation to a historical earthquake remain unknown.

This research demonstrated the benefit of applying the pseudo-3D GPR technique in identifying subsurface offset features associated with the recent faulting event. The offset amount and distribution are important parameters to understand the coseismic behavior of active faults. The offset features might quickly disappear in regions with intense sedimentation and or severe artificial modification. The pseudo-3D GPR technique is helpful to uncover the buried offsets related to the last surface-rupturing earthquakes in those regions so that the slip distribution and rupture extent of earthquakes in the past can be well established. However, careful consideration is still required for site selection and data analysis. 


\section{Abbreviations}

GPR: Ground-penetrating radar; CMP: Common mid-point; GNSS: Global navigation satellite system; MTL: Median Tectonic Line; NMO: Normal move-out; SRTM: Shuttle Radar Topographic Mission

\section{Supplementary Information}

The online version contains supplementary material available at https://doi. org/10.1186/s40645-022-00466-7.

Additional file 1. The 3D model of the paleochannel A.

\section{Acknowledgements}

We thank Toshimichi Nakanishi for helping the survey planning. We are grateful to Kaoru Taniguchi, Daichi Nishioka, and Cosmo Kajii for their assistance in the field. We thank the landowners of the study site for the permission to survey their properties. AP is funded by the MEXT Scholarship from the Japanese Government for his Ph.D. study at Doshisha University. Finally, we thank an anonymous reviewer and Hisao Kondo for their reviews which improved this manuscript.

\section{Authors' contributions}

AP processed and interpreted GPR data, analyzed the results, and drafted the original manuscript. HK led, conceptualized, supervised the study, conducted the 3D modeling, and reviewed the manuscript. YK processed and interpreted the GPR data from the survey in 2018. HT conceptualized, supervised the study, wrote and reviewed the manuscript. All authors participated in the field survey, read and approved the final manuscript.

\section{Funding}

This study was supported by the Grant-in-Aid for Scientific Research No. 18 K03768 to HK from the Japan Society of the Promotion of Science (JSPS)

\section{Availability of data and materials}

The datasets of the study are available upon request to HK (kimura@criepi. denken.or.jp).

\section{Declarations}

\section{Competing interests}

The authors declare that they have no competing interests.

\section{Author details}

${ }^{1}$ Graduate School of Science and Engineering, Doshisha University, 1-3 Tatara-Miyakodani, Kyotanabe, Kyoto 610-0394, Japan. ${ }^{2}$ Central Research Institute of Electric Power Industry (CRIEPI), 1646 Abiko, Abiko, Chiba 270-1194, Japan. ${ }^{3}$ Department of Environmental Systems Science, Faculty of Science and Engineering, Doshisha University, 1-3 Tatara-Miyakodani, Kyotanabe, Kyoto 610-0394, Japan. ${ }^{4}$ Research Center of Geotechnology, National Research and Innovation Agency (BRIN), Bandung 40135, Indonesia.

Received: 16 July 2021 Accepted: 5 January 2022

Published online: 20 January 2022

\section{References}

Beauprêtre S, Garambois S, Manighetti I, Malavieille J, Sénéchal G, Chatton M, Davies T, Larroque C, Rousset D, Cotte N, Romano C (2012) Finding the buried record of past earthquakes with GPR-based paleoseismology: a case study on the Hope fault, New Zealand. Geophys J Int 189:73-100. https://doi.org/10.1111/j.1365-246X.2012.05366.x

Benson AK (1995) Applications of ground penetrating radar in assessing some geological hazards: examples of groundwater contamination, faults, cavities. J Appl Geophys 33:177-193. https://doi.org/10.1016/0926-9851(95) 90040-3
Cai J, McMechan GA, Fisher MA (1996) Application of ground-penetrating radar to investigation of near-surface fault properties in the San Francisco Bay region. Bull Seismol Soc Am 86:1459-1470

Chow J, Angelier J, Hua J-J, Lee J-C, Sun R (2001) Paleoseismic event and active faulting: from ground penetrating radar and high-resolution seismic reflection profiles across the Chihshang Fault, eastern Taiwan. Tectonophysics 333:241-259. https://doi.org/10.1016/S0040-1951(00)00277-8

Davis JL, Annan AP (1989) Ground-penetrating radar for high-resolution mapping of soil and rock stratigraphy. Geophys Prospect 37:531-551. https:// doi.org/10.1111/j.1365-2478.1989.tb02221.x

DeMets C, Gordon RG, Argus DF (2010) Geologically current plate motions. Geophys J Int 181:1-80. https://doi.org/10.1111/j.1365-246X.2009.04491.x

Dujardin J-R, Bano M, Schlupp A, Ferry M, Munkhuu U, Tsend-Ayush N, Enkhee B (2014) GPR measurements to assess the Emeelt active fault's characteristics in a highly smooth topographic context. Mongolia Geophys J Int 198:174-186. https://doi.org/10.1093/gii/ggu130

Fitch TJ (1972) Plate convergence, transcurrent faults, and internal deformation adjacent to Southeast Asia and the western Pacific. J Geophys Res 77:4432-4460. https://doi.org/10.1029/JB077i023p04432

Goto H, Nakata T, Tsutsumi H, Okumura K, Imaizumi T, Nakamura T, Watanabe T (2001) The Latest Surface-Faulting Events on the Median Tectonic Line in Shikoku, Southwest Japan, Based on Mini-Trenching and Geoslicer studies. J Seismol Soc Japan 2nd ser (Zisin) 53:205-219 (in Japanese with English abstract)

Goto H, Tsutsumi H, Toda S (2003) Timing and Displacement of the Most Recent Surface Faulting on the Hatano Fault of the Median Tectonic Line Active Fault System, Southwest Japan . J Geogr (Chigaku Zasshi) 112:531-543. https://doi.org/10.5026/jgeography.112.4_531(in Japanese with English abstract)

Green A, Gross R, Holliger K, Horstmeyer H, Baldwin J (2003) Results of 3-D georadar surveying and trenching the San Andreas fault near its northern landward limit. Tectonophysics 368:7-23. https://doi.org/10.1016/S00401951(03)00147-1

Gross R, Green A, Holliger K, Horstmeyer H, Baldwin J (2002) Shallow geometry and displacements on the San Andreas Fault near Point Arena based on trenching and 3-D georadar surveying. Geophys Res Lett 29:34. https:// doi.org/10.1029/2002GL015534

Ito T, Ikawa T, Yamakita S, Maeda T (1996) Gently north-dipping Median Tectonic Line (MTL) revealed by recent seismic reflection studies, southwest Japan. Tectonophysics 264:51-63. https://doi.org/10.1016/S00401951(96)00117-5

Jol H (2008) Ground penetrating radar: theory and applications, 1st edn. Elsevier BV, Hoboken

Kimura H, Nakanishi T, Katsuki K, Hong W, Matsuyama H, Takemura K (2019) Holocene activity of the Asamigawa fault detected from sediment cores and a ground-penetrating radar cross-section in the Beppu area, southwestern Japan. Quat Int 503:87-96. https://doi.org/10.1016/j.quaint. 2018.09.005

Malik JN, Sahoo AK, Shah AA (2007) Ground-penetrating radar investigation along Pinjore Garden Fault: Implication toward identification of shallow subsurface deformation along active fault, NW Himalaya. Curr Sc 93:1422-1427

McClymont AF, Green AG, Kaiser A, Horstmeyer H, Langridge R (2010) Shallow fault segmentation of the Alpine fault zone, New Zealand revealed from 2- and 3-D GPR surveying. J Appl Geophys 70:343-354. https://doi.org/ 10.1016/j.jappgeo.2009.08.003

McClymont AF, Green AG, Villamor P, Horstmeyer H, Grass C, Nobes DC (2008) Characterization of the shallow structures of active fault zones using 3-D ground-penetrating radar data. J Geophys Res Solid Earth 113:B10315. https://doi.org/10.1029/2007JB005402

Morino M, Okada A (2002) Faulting history of the Median Tectonic Line active fault system in Shikoku, based on re-examination of trench survey results. Act Fault / Paleoearthquake Res Rep 2:153-182 (in Japanese with English abstract)

Okada A (1980) Quaternary faulting along the Median Tectonic Line of southwest Japan. In: Ichikawa K (ed) Median Tectonic Line of southwest Japan. Memoir Geological Society Japan 18, pp 79-108

Okada A, Tsutsumi H (1997) Holocene Activity of the Chichio Fault, the Median Tectonic Line Active Fault System, Southwest Japan, based on Trenching Studies. J Geogr (Chigaku Zasshi) 106:644-659. https://doi.org/10.5026/ jgeography.106.5_644 (in Japanese with English abstract) 
Saito M, Tsukuda E, Okada A, Furusawa A (1997) AT Tephra Found in the Fluvial Lower Terrace Deposits at the Northern Wakayama City, and the Slip Rate of the Negoro fault, Median Tectonic Line Active Fault System, Central Japan. Quat Res (Daiyonki-Kenkyu) 36:277-280. https://doi.org/10.4116/ jaqua.36.277 (in Japanese)

Sherrif RE, Geldart LP (1995) Exploration seismology, 2nd edn. Cambridge University Press, Cambridge

Slater L, Niemi TM (2003) Ground-penetrating radar investigation of active faults along the Dead Sea Transform and implications for seismic hazards within the city of Aqaba, Jordan. Tectonophysics 368:33-50. https://doi. org/10.1016/S0040-1951(03)00149-5

Smith DG, Jol HM (1995) Ground penetrating radar: antenna frequencies and maximum probable depths of penetration in Quaternary sediments. J Appl Geophys 33:93-100. https://doi.org/10.1016/0926-9851(95)90032-2

Sugiyama Y (1994) Neotectonics of Southwest Japan due to the right-oblique subduction of the Philippine Sea plate. Geofísica Int. 33:53-76. https:// doi.org/10.22201/igeof.00167169p.1994.33.1.540

Sylvester AG (1988) Strike-slip faults. Geol Soc Am Bull 100:1666-1703

Tsutsumi H, Goto H (2006) Surface Offsets Associated with the Most Recent Earthquakes along the Median Tectonic Line Active Fault Zone in Shikoku, Southwest Japan. J Seismol Soc Japan 2nd ser (Zisin) 59:117-132 (in Japanese with English abstract)

Tsutsumi H, Okada A (1996) Segmentation and Holocene surface faulting on the Median Tectonic Line, southwest Japan. J Geophys Res 101:58555871. https://doi.org/10.1029/95JB01913

Tsutsumi H, Okada A, Nakata T, Ando M, Tsukuda T (1991) Timing and displacement of Holocene faulting on the Median Tectonic Line in central Shikoku, southwest Japan. J Struct Geol 13:227-233. https://doi.org/10. 1016/0191-8141(91)90069-U

Vanneste K, Verbeeck K, Petermans T (2007) Pseudo-3D imaging of a low-sliprate, active normal fault using shallow geophysical methods: The Geleen fault in the Belgian Maas River valley. Geophysics 73:B1-B9. https://doi. org/10.1190/1.2816428

\section{Publisher's Note}

Springer Nature remains neutral with regard to jurisdictional claims in published maps and institutional affiliations.

\section{Submit your manuscript to a SpringerOpen ${ }^{\circ}$ journal and benefit from:}

- Convenient online submission

- Rigorous peer review

- Open access: articles freely available online

- High visibility within the field

- Retaining the copyright to your article 